\title{
Effect of the use of industrial excess heat in district heating on greenhouse gas emissions: A systems perspective
}

\author{
Jenny Ivner and Sarah Broberg Viklund \\ Linköping University Post Print
}

Tweet

N.B.: When citing this work, cite the original article.

Original Publication:

Jenny Ivner and Sarah Broberg Viklund, Effect of the use of industrial excess heat in district heating on greenhouse gas emissions: A systems perspective, 2015, Resources, Conservation and Recycling, (100), 81-87.

http://dx.doi.org/10.1016/j.resconrec.2015.04.010

Copyright: Elsevier

http://www.elsevier.com/

Postprint available at: Linköping University Electronic Press

http://urn.kb.se/resolve?urn=urn:nbn:se:liu:diva-118080 


\title{
Effect of the use of industrial excess heat in district heating on greenhouse gas emissions: A systems perspective
}

\author{
Jenny Ivnera, Sarah Broberg Viklund ${ }^{a, *}$ \\ ${ }^{a}$ Department of Management and Engineering, Division of Energy Systems, Linköping University, SE-581 83 \\ Linköping, Sweden \\ ${ }^{*}$ Corresponding author: Department of Management and Engineering, Division of Energy Systems, Linköping \\ University, SE-581 83 Linköping, Sweden. E-mail address: sarah.broberg.viklund@liu.se. Phone number: +46 \\ 13281103
}

\begin{abstract}
European policy promotes increased use of excess heat as a means to increase the efficiency of resource use. By studying possible effects on greenhouse gases, this article aims to analyze and discuss system aspects of the use of industrial excess heat in district heating. Effects on greenhouse gas emissions are studied by applying different energy market conditions with different system boundaries in time and space. First, life cycle assessment is used to assess the introduction of excess heat in district heating in a contemporary system with different geographical system boundaries. Thereafter, future energy market scenarios for Europe are investigated to explore possible future outcomes. This study concludes that both the heat production system and the energy market conditions affect the system emission effects of using excess heat in district heating. Industrial excess heat in district heating can be beneficial even if it leads to reduced local electricity production when unused biomass can be used to replace fossil fuels. It is recommended that a strengthened EU policy should encourage the use of biomass where it has the most favorable effects from a systems perspective to ensure emission reductions when industrial excess heat is used in district heating.
\end{abstract}

Key words: industrial excess heat, industrial waste heat, district heating, ENPAC, LCA, emission mitigation

\section{Introduction}

The European Union (EU) has developed strategic objectives for 2020 that are intended to achieve sustainable economic growth, increase EU competitiveness, and achieve a secure energy supply. As part of this strategy, the EU set 20-20-20 climate targets. The targets are that there will be a $20 \%$ reduction in greenhouse gas (GHG) emissions compared to the 1990 level, that $20 \%$ of the final energy used will be derived from renewable resources, and a $20 \%$ reduction in primary energy use by implementing energy efficiency measures (European Commission, 2010). However, the European Commission agreed to a new framework for EU energy and climate targets in October 2014. The new targets for 2030 aim to reduce GHG emissions by $40 \%$, increase the share of renewables by $27 \%$, and increase energy efficiency 
by $27 \%$ (European Commission, 2014). These targets are related in that improved energy efficiency may at the same time reduce GHG emissions. Even though the EU and its member states promote energy efficiency, forecasts indicate that the measures taken will not be sufficient and that the target of a 20 per cent reduction in primary energy use will not be met. Estimates show that merely half of the $20 \%$ objective will be achieved by 2020 (European Commission, 2011) Therefore, additional effort is needed to get the EU on the right course and further improve energy efficiency.

Measures to tackle these challenges are presented in The Energy Efficiency Plan 2011 (European Commission, 2011). For example, effective heat recovery systems could utilize excess heat from electricity and industrial production processes. This unused resource could among others be used for heating and cooling services (European Commission, 2011), thus reducing the need for primary energy resources and reduce $\mathrm{CO}_{2}$ emissions (Cruz et al., 2011; Nomura et al., 2010; Ruohonen et al., 2010; Thekdi and Belt, 2011). Policies are needed to achieve the energy savings target. The Energy Efficiency Directive 2012/12/EU (also known as EED) provides a framework for the development of an energy efficiency policy. The directive appoints recovery of excess heat as one way to reach the EU target (European Commission, 2012). With the aim of promoting an efficient energy supply, the national proposal for the implementation of the EED in Sweden states that a cost-benefit analysis should be performed, in the context of certain investments, to evaluate the use of excess heat in comparison with other thermal supply systems (Ministry of Enterprise Energy and Communications, 2013). Connolly et al. (2014) also highlight industrial excess heat as an unused resource that could be used to improve energy efficiency and reduce climate impact in Europe.

Estimates of the total industrial excess heat in Sweden conclude that there is a large unutilized heat potential (Broberg et al., 2012; Cronholm et al., 2009; Holmgren and Sjödin, 2008). Despite somewhat rough estimates and uncertainty in the final figures, the estimated several TWh of industrial excess heat per year indicates the potential of this resource, even though it may not be technically or economically feasible to recover the full potential. For Europe as a whole, the figure would be even higher (Persson et al., 2012), as merely $3 \%$ of the available industrial excess heat is utilized today (Connolly et al., 2012).

In Sweden, district heating (DH) companies are currently obliged to negotiate with potential new heat suppliers, although they do have the option of rejecting these heat deliveries. Delivery of excess heat into existing DH grids is, however, problematic. The challenges posed include management of intermittent energy supplies, the need to divide energy generation businesses into separate production and distribution companies, and the fact that additional heat in DH systems based on combined heat and power (CHP) could reduce electricity production and hence overall system efficiency (SOU (Ministry of Enterprise Energy and Communications), 2005; SOU (Ministry of Enterprise Energy and Communications), 2011). Recognising these challenges, the Swedish government bill states, "The DH company has no obligation to allow regulated access if the company can show that there is a risk that it will suffer damage as a result of the access." (Swedish Government, 2014). This means that Swedish policy neither promotes nor advises against using excess heat in DH. Nor does the 
policy distinguish between factors such as different production systems for $\mathrm{DH}$, that is, whether the current systems are CHP-based or not.

This article aims to analyze and discuss systems aspects of the use of industrial excess heat in district heating. The analyses are based on calculations of GHG emissions using life cycle assessment (LCA) and general energy price and carbon balance (ENPAC) scenarios (Axelsson et al., 2009; Harvey and Axelsson, 2010). Combining these two methods enables a comprehensive systems analysis, which is used for a discussion of policy implications for excess heat use in DH. This paper focuses on the use of industrial excess heat in a Swedish perspective. Thus excess heat generated at other facilities will not be discussed. Technical changes in energy facilities are also not discussed.

\section{Systems aspects of CHP and industrial excess heat}

There are two main production technologies for DH, CHP and heat boilers. In a CHP plant both electricity and heat are produced simultaneously. Due to the simultaneous production of heat and electricity, the total plant efficiency is high compared to condensing power plants (approximately $90 \%$ compared to approximately $40 \%$ ). CHP is therefore generally considered to be an energy efficient electricity and heat production system.

Industrial excess heat can also be recovered and used as a thermal source for DH. The heat can be used to heat either the supply or return water in DH. In 2012 approximately $7 \%$ of the supplied energy in the Swedish DH systems came from excess heat (Swedish District Heating Association, 2014). When it comes to European DH systems, Sweden reports the largest share $^{1}$ of the total industrial heat deliveries: approximately $70 \%$ of the reported deliveries in 2008 (Persson and Werner, 2012).

Other types of heat production are displaced if excess heat is used in the DH system. If heat produced by CHP is displaced, less electricity will be produced in the CHP plant. This is because, at a constant heat demand, the use of excess heat will result in a decreased demand for CHP-produced heat. Other complementary electricity generation technologies will then cover the reduced electricity production from the CHP plant. On the other hand, increasing the use of excess heat in the DH system reduces the need for fuel in the thermal production system. These fuel resources can then be used by alternative users. This makes the consequences of such systems intervention complex to assess.

Given this background, the complexity of the problem needs to be considered to avoid the risk that excess heat use leads to undesirable side effects. Figure 1 illustrates the relationship between thermal sources in a DH system, its fuel use, electricity distribution, and industrial excess heat.

\footnotetext{
${ }^{1}$ Compared to Sweden, France, Denmark, Germany, and Italy.
} 


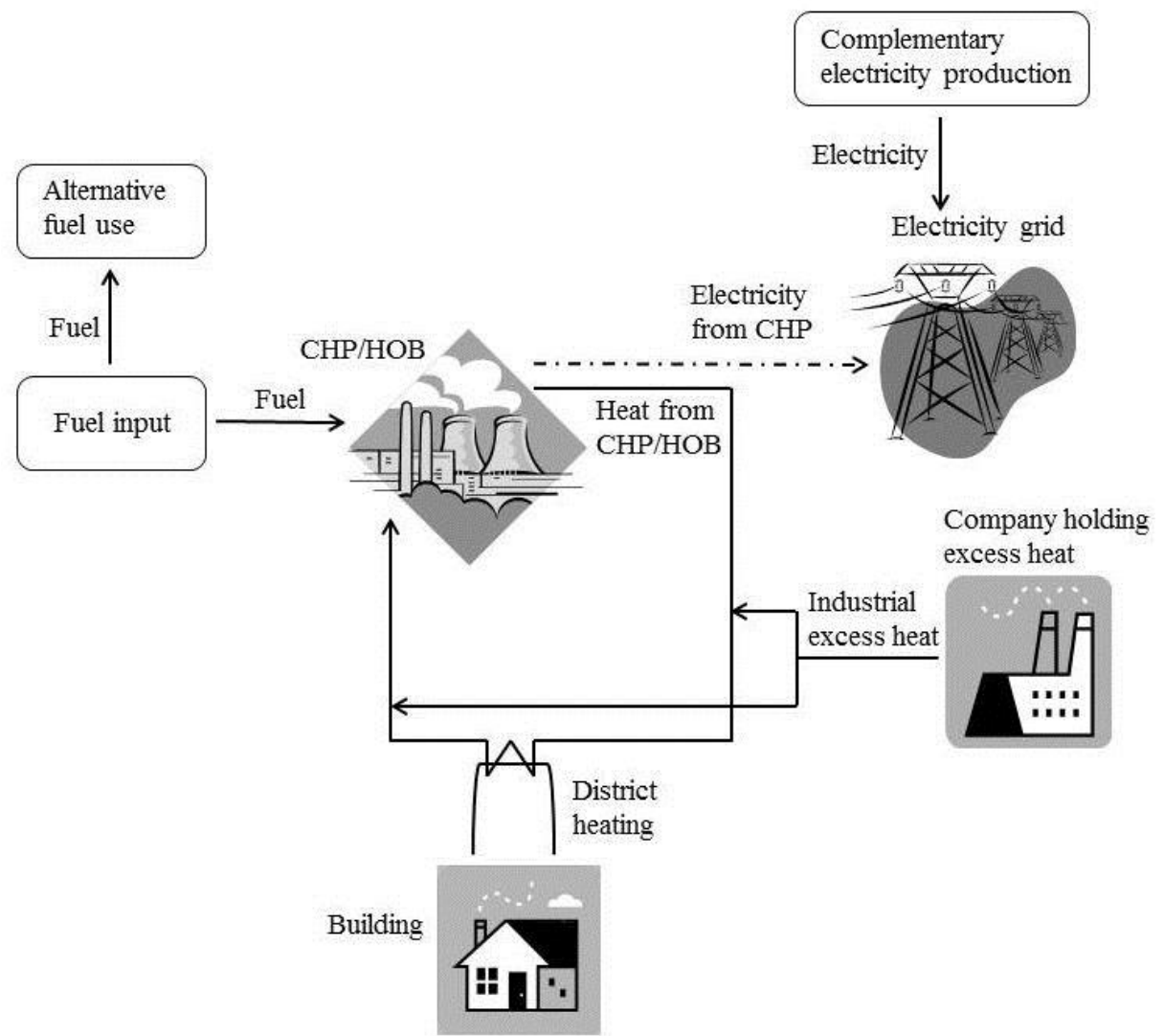

Figure 1 System aspects of thermal source in a DH system and its fuel use, electricity distribution, and industrial excess heat $(\mathrm{CHP}=$ combined heat and power, $\mathrm{HOB}=$ heat-only boiler $)$

A financial support system, the electricity certificate system, was introduced to increase the proportion of electricity production derived from renewable resources (SEA, 2010). The profitability of investments in new bio-based CHP plants has been shown to have increased significantly with the introduction of the certificate system (Knutsson et al., 2006). Thus this financial support has increased the profitability of bio-CHP compared to excess heat utilization. Competition between the two thermal supply systems has previously been discussed from an economic perspective (Broberg Viklund, 2014; Grönkvist et al., 2008; Holmgren and Sjödin, 2008). However, environmental impacts were omitted from these papers.

\section{Research methods}

This article assesses systems aspects of the use of industrial excess heat in DH system. This assessment is made in two steps. First, the introduction of industrial excess heat in an average contemporary Swedish DH system is assessed for different production cases using LCA. In the second step, the ENPAC tool is used to further explore systems aspects of the use of excess heat in DH, focusing on future energy market for the years 2020 and 2030. Systems approaches in the tools are illustrated in Figure 2. 


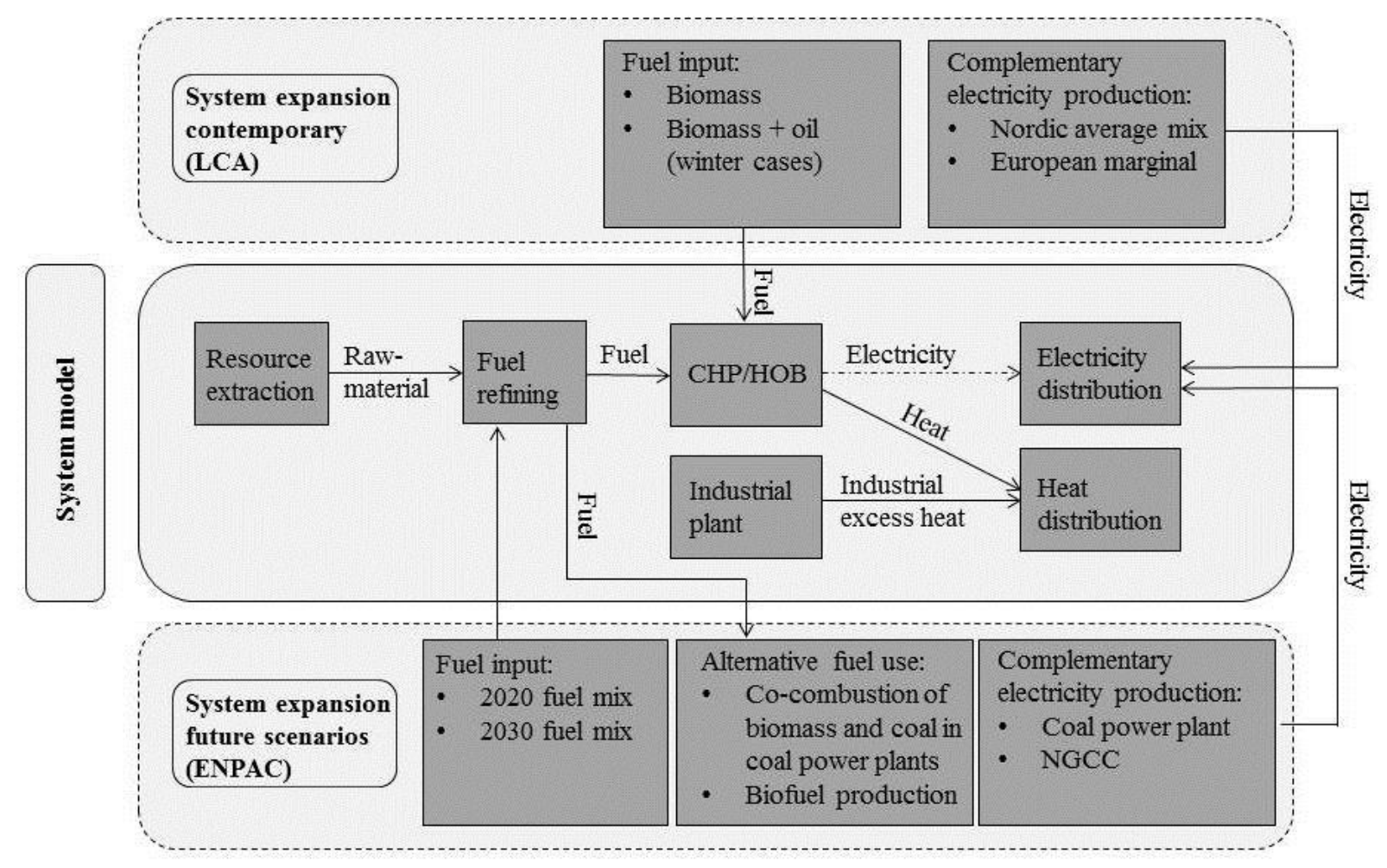

Figure 2 Systems approaches in the tools used. The "system model" together with the "the system expansion contemporary" constitute the LCA approach, while the "system model" together with the "system expansion future scenarios" constitute the ENPAC scenarios approach. (CHP = combined heat and power, HOB = heatonly boiler, NGCC = natural gas combined cycle)

Two different assessment tools were chosen in order to illuminate a wide range of cases of industrial excess heat in contemporary DH settings, as well as to explore the possible effects of future energy markets. This methodological choice was made to mirror many aspects of this complex issue and to identify risks for undesirable side effects of the use of industrial excess heat in district heating. The use of more than one analytical tool to scrutinize different energy system choices has been recommended by researchers such as Hochschorner and Finnveden (2003) and Pietrapertosa et al. (2009). Being aware of a wider range of consequences from systems changes enables policy makers to make more informed decisions (English et al., 1999) and also helps policy makers avoid undesirable side effects from the changes at hand (Wrisberg and Udo de Haes, 2002).

\subsection{Life cycle assessment of contemporary DH production systems}

LCA is predominantly used by the scientific community to assess environmental impacts and the use of resources throughout a products or technology's life cycle - from production, through use, to disposal (ISO, 2006a; ISO, 2006b). A product in this sense is not necessarily a physical item, but may also be a service, such as DH. LCA has been used to evaluate different aspects of the choices of energy carriers for DH as well as options for electricity generation using CHP (Eriksson et al., 2007; Ghafghazi et al., 2011; Guest et al., 2011).

3.1.1 Analysis framework and production cases for substituted district heating production 
In this article LCA is used as a framework to assess what happens if industrial excess heat is introduced in different production systems for $\mathrm{DH}$. To make this framework manageable, standardized production cases delivering a functional unit of $1 \mathrm{GJ}$ heat for contemporary DH from boilers and CHP plants were used. Environmental performance for the DH was then calculated for biomass-based production in summer and winter cases. When excess heat is used in a DH system based on CHP, the electricity production in the CHP plants is reduced proportionally. For CHP-based DH, environmental performance was calculated for two different types of substituted electricity: Nordic average mix, and marginal (coal, which is also the baseline in the ENPAC tool). All cases are also calculated with SimaPro software (Product Ecology (PRé) consultants, 2008) for summer and winter instances. This results in six production cases (Table 1).

Table 1 Production cases for substituted district heating in the LCA calculations

\begin{tabular}{|c|c|c|c|c|c|c|}
\hline Production case & A & B & $\mathrm{C}$ & $\mathrm{D}$ & $\mathrm{E}$ & $\mathrm{F}$ \\
\hline Plant type & \multicolumn{2}{|c|}{ HOB } & \multicolumn{4}{|c|}{ CHP } \\
\hline $\begin{array}{l}\text { Substituted electricity } \\
\mathrm{CO}_{2} \text {-eq }\left[\mathrm{kg} / \mathrm{MWh}_{\mathrm{el}}\right]\end{array}$ & \multicolumn{2}{|c|}{ N/A } & \multicolumn{2}{|c|}{$\begin{array}{l}\text { Nordic mix } \\
64 \\
\end{array}$} & \multicolumn{2}{|c|}{$\begin{array}{c}\text { EU Marginal } \\
880 \\
\end{array}$} \\
\hline Season & Summer & Winter & Summer & Winter & Summer & Winter \\
\hline
\end{tabular}

\subsubsection{Life cycle data and allocation}

Life cycle data for fuels were primarily obtained from Ecoinvent (Ecoinvent Centre, 2010) and complemented with specific boiler and fuel data from the Swedish Environment Research Institute (Uppenberg et al., 2001). For the winter cases it was assumed that $15 \%$ of the fuel comes from oil, which is an average peak load estimation for Swedish heat production (Swedish District Heating Association, 2005). Evaluation of the impact on GHG emissions was based on GWP100, where all GHGs are expressed in terms of $\mathrm{CO}_{2}$ equivalents $\left(\mathrm{CO}_{2}\right.$-eq.) and their effect on global heat absorption over 100 years (Product Ecology (PRé) consultants, 2008). Global warming potential (GWP) for excess heat was allocated zero emissions. As this paper is written in a Swedish context, for CHP-based DH, $27.5 \%$ of all GHG was allocated to the heat, and the rest to the electricity in accordance with recommendations from the Swedish District Heating Association and Svensk Energi (the Swedish association of electricity producers) (2011). Electricity efficiency (alpha value) in the CHP plants was estimated to be $30 \%$ (meaning that 1.43 GJ fuel is used to produce 0.43 GJ electricity and 1 GJ heat). Production losses have been ignored.

\subsection{Future energy market scenarios}

Scenarios predicting future energy markets can be used to handle the uncertainty regarding the future energy market, and then to identify robust investments and evaluate climate benefits. Possible cornerstones of a future energy market can be predicted by using consistent energy market scenarios (EMS) in which energy market parameters within a given scenario are related to each other. This means that it is possible to explore the future effects of industrial excess heat in district heating. 
The emission performance of excess heat utilization in DH was evaluated using the ENPAC tool. The same functional unit as in the LCA analysis (1 GJ heat delivered) was used to analyze the effects on GHG emissions for different future energy markets. Scenarios predicting future energy markets for 2020 and 2030 were used to calculate the possible effects of industrial excess heat in DH under different medium- and long-term energy market conditions. Several previous research studies have used the ENPAC tool to evaluate the profitability of energy investments and their effects on global $\mathrm{CO}_{2}$ emissions (Broberg Viklund and Johansson, 2014; Johansson et al., 2013; Jönsson et al., 2008).

Inputs to the ENPAC tool include fossil fuel prices (taken from the scenarios presented in IEA (2011)), charges for emitting $\mathrm{CO}_{2}$, and emissions related to fuels used. Emission factors are taken from (Gode et al., 2011). Emissions associated with different fuels are calculated and include both well-to-gate emissions (emission associated with fuel extraction, processing, and distribution) and emissions from combustion. $\mathrm{CO}_{2}, \mathrm{CH}_{4}$, and $\mathrm{N}_{2} \mathrm{O}$ are included when the emissions are calculated and they are presented as $\mathrm{CO}_{2}$-eq. In the calculations of the effects on GHGs, biomass was considered a limited resource on the market and a marginal electricity approach was used. Based on the inputs to the ENPAC tool, the marginal technology for electricity production (build margin) and the marginal user of biomass were determined. The build margin technology is the technology with the lowest cost for electricity production, while the marginal user of biomass is the user with the highest willingness to pay for biomass. The scenario tool can choose between two marginal users of biomass, either co-combustion of biomass and coal in coal-condensing power plants or production of the renewable transportation fuel Fischer-Tropsch (FT) diesel, hereafter referred to as biofuel.

Axelsson and Pettersson (2014) have identified two price-setting, heat-producing technologies, and thus these two potential DH systems were considered. They are a Swedish DH system using bio-based HOBs (bio-HOB) and a Swedish system using bio-based combined heat and power (bio-CHP). When excess heat is delivered to a DH system, the current heat production (in this study by bio- $\mathrm{HOB}^{2}$ or bio- $\mathrm{CHP}^{3}$ systems) will be displaced. Heat recovery in both systems will replace energy originating mainly from biomass, and thus biomass will be released and used by the marginal user of biomass. However, when excess heat is used in a DH system based on CHP, the electricity production in the CHP plants will be reduced. Therefore changes in electricity production (increase or decrease) within the system boundary will result in equal changes in marginal electricity production (increase or decrease) (Dotzauer, 2010; Sjödin and Grönkvist, 2004). These changes in energy supply within a system affect global GHG emissions. The energy market data derived from the ENPAC tool can be seen in Table 2. A more thorough description of the tool, its underlying

\footnotetext{
${ }^{2}$ Figures given for 2020 / 2030: This system consists mainly of bio-based HOB (84 \% / $85 \%$ ) and a small proportion of coal-HOB (4\% / 4\%), natural gas-HOB (6\% / $2 \%)$, oil HOB $(5 \% / 4 \%)$, and other renewables $(1 \% / 4 \%)$.

${ }^{3}$ Figures given for 2020 / 2030: This system consists mainly of bio-based CHP (46\% / $54 \%$ ) and bio-based HOB $(30 \% / 28 \%)$ and a small proportion of coal-CHP (5\% / $3 \%)$, natural gas-CHP (7 \% / $6 \%)$, oil-CHP (1 $\% / 0 \%)$, coal-HOB (2\% / $1 \%)$, natural gas-HOB (2\% / $1 \%)$, oil-HOB (2\% / $1 \%)$, heat pumps $(6 \% / 4 \%)$, and other renewables (1\%/6\%).
} 
assumptions and input data can be found in (Axelsson et al., 2009; Axelsson and Pettersson, 2014; Harvey and Axelsson, 2010).

Table 2 Energy market scenarios (EMS) data for 2020 and 2030. Negative values for the $\mathrm{CO}_{2}$-eq. emissions correspond to increased emissions. (NGCC = natural gas combined cycle, FT = Fischer-Tropsch). (Input data to the tool, that is fuel prices on the world market and $\mathrm{CO}_{2}$ emission charges are taken from World Energy Outlook 2011 (IEA, 2011).

\begin{tabular}{|c|c|c|c|c|c|c|}
\hline $\begin{array}{l}\text { Energy } \\
\text { market } \\
\text { scenario }\end{array}$ & $1^{\mathrm{a}}$ & $2^{\mathrm{b}}$ & $3^{\mathrm{c}}$ & $4^{\mathrm{d}}$ & $5^{\mathrm{e}}$ & $6^{\mathrm{f}}$ \\
\hline Year & 2020 & 2020 & 2020 & 2030 & 2030 & 2030 \\
\hline \multicolumn{7}{|c|}{ Marginal user of biomass } \\
\hline & FT & FT & Coal & FT & FT & Coal \\
\hline \multicolumn{7}{|c|}{$\mathrm{CO}_{2}$-eq. emissions reduction from use of biomass [kg/MWhfuel] } \\
\hline & 118 & 118 & 401 & 119 & 119 & 401 \\
\hline \multicolumn{7}{|c|}{ Build margin technology for electricity production } \\
\hline & Coal & Coal & Coal & Coal & Coal & NGCC \\
\hline \multicolumn{7}{|c|}{$\mathrm{CO}_{2}$-eq. emissions from marginal production of electricity [kg/MWhel] } \\
\hline & 856 & 856 & 856 & 805 & 805 & 376 \\
\hline \multicolumn{7}{|c|}{$\begin{array}{l}\text { CO2-eq. emissions reduction if industrial excess heat is used in a DH system } \\
{\left[\mathrm{kg} / \mathrm{MWh} \mathrm{h}_{\text {heat }}\right]}\end{array}$} \\
\hline $\begin{array}{l}\text { DH system: } \\
\text { bio-HOB }\end{array}$ & 164 & 164 & 413 & 154 & 154 & 408 \\
\hline $\begin{array}{l}\text { DH system: } \\
\text { bio-CHP }\end{array}$ & -28 & -28 & 250 & -40 & -40 & 397 \\
\hline
\end{tabular}

${ }^{\mathrm{a}}$ Fuel prices on the world market: crude oil 118 \$barrel, natural gas $11 \$ / \mathrm{Mbtu}$, coal $109 \$ /$ tonne, $\mathrm{CO}_{2}$ emission charge 23 EUR/tonne.

${ }^{\mathrm{b}}$ Fuel prices on the world market: crude oil $109 \$ /$ barrel, natural gas $10 \$ / \mathrm{Mbtu}$, coal $106 \$$ tonne, $\mathrm{CO}_{2}$ emission charge 23 EUR/tonne.

${ }^{\mathrm{c}}$ Fuel prices on the world market: crude oil 97 \$barrel, natural gas $10 \$ / \mathrm{Mbtu}$, coal $93 \$ /$ tonne, $\mathrm{CO}_{2}$ emission charge 34 EUR/tonne.

${ }^{\mathrm{d}}$ Fuel prices on the world market: crude oil $135 \$ /$ barrel, natural gas $13 \$ / \mathrm{Mbtu}$, coal $116 \$ /$ tonne, $\mathrm{CO}_{2}$ emission charge 30 EUR/tonne.

${ }^{\mathrm{e}}$ Fuel prices on the world market: crude oil $117 \$ / \mathrm{barrel}$, natural gas $12 \$ / \mathrm{Mbtu}$, coal $109 \$ /$ tonne, $\mathrm{CO}_{2}$ emission charge 30 EUR/tonne.

${ }^{\mathrm{f}}$ Fuel prices on the world market: crude oil 97 \$/barrel, natural gas $10 \$ / \mathrm{Mbtu}$, coal $74 \$ /$ tonne, $\mathrm{CO}_{2}$ emission charge 72 EUR/tonne.

\section{Results and analysis}

4.1 Systems aspects of excess heat in contemporary DH systems

Figure 3 shows that the effects on GHG emissions from the use of industrial excess heat in DH depend heavily on whether the substituted heat is produced in HOB or in CHP plants. From an LCA perspective it is always positive to substitute heat from HOB (scenarios A and $B)$. These results depend on the fact that industrial excess heat is regarded as a free resource 
with zero emission allocated to it. The effects of excess heat in CHP-based DH depend on the system boundaries chosen for lost electricity production. If a broad systems perspective is applied to the lost electricity production (a central European production mix -scenarios $\mathrm{E}$ and F), it is distinctly negative to substitute heat production from CHP with industrial excess heat, even though the excess heat has no environmental impact. These results arise because the European electricity production mix is associated with high GHG emissions. If a more restricted systems approach is applied when calculating GHG emissions, and lost electricity production is assumed to be equal to the average Nordic electricity production mix, the results are less obvious. However, there are still increases in GHG emissions (scenarios C and D). Hence the choice of allocation of emissions to the (lost) electricity production is critical to the outcome of the calculations. This means that the future electricity system and production mix will determine whether it is beneficial to utilize industrial excess heat in CHP-based district heating.

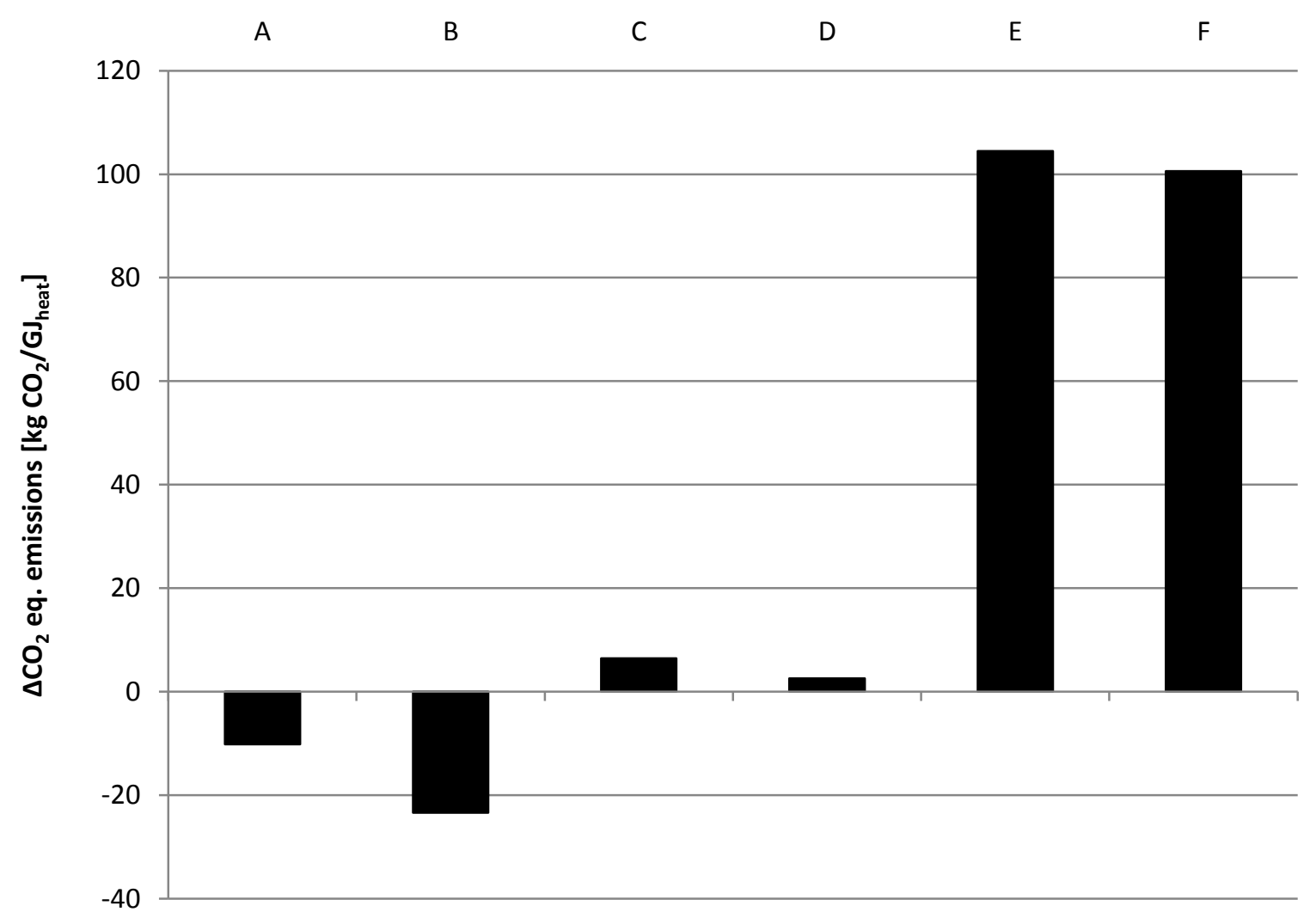

Figure 3 Potential effects on GHG emissions from the LCA calculations when excess heat is used in DH. Each bar represents a DH production scenario as presented in Table 1.

4.2 Systems aspects of excess heat in DH in future energy markets

When applying future energy market scenarios with restrictions on biomass availability and various marginal electricity producers, the effects on GHG emissions due to using industrial excess heat in DH differ somewhat from the LCA calculations (Figure 4). Similar to LCA production cases $\mathrm{A}$ and $\mathrm{B}$, the use of excess heat in HOB-based $\mathrm{DH}$ reduces the GHG emissions in all future energy market scenarios studied (black bars in Figure 4). However, when using industrial excess heat in the CHP-based DH systems, GHG emissions are reduced 
in the scenarios where released biomass is co-fired (and replaces coal) in coal power plants (EMS-3 and EMS-6). The emission consequences follow the same trend for both mediumand long-term scenarios, with a greater GHG reduction in the long-term scenario (EMS-6). This result is a consequence of different build margin technologies for electricity production. Build margin technology for electricity production is coal power plants in EMS-3, while it is natural gas combined cycle in EMS-6.

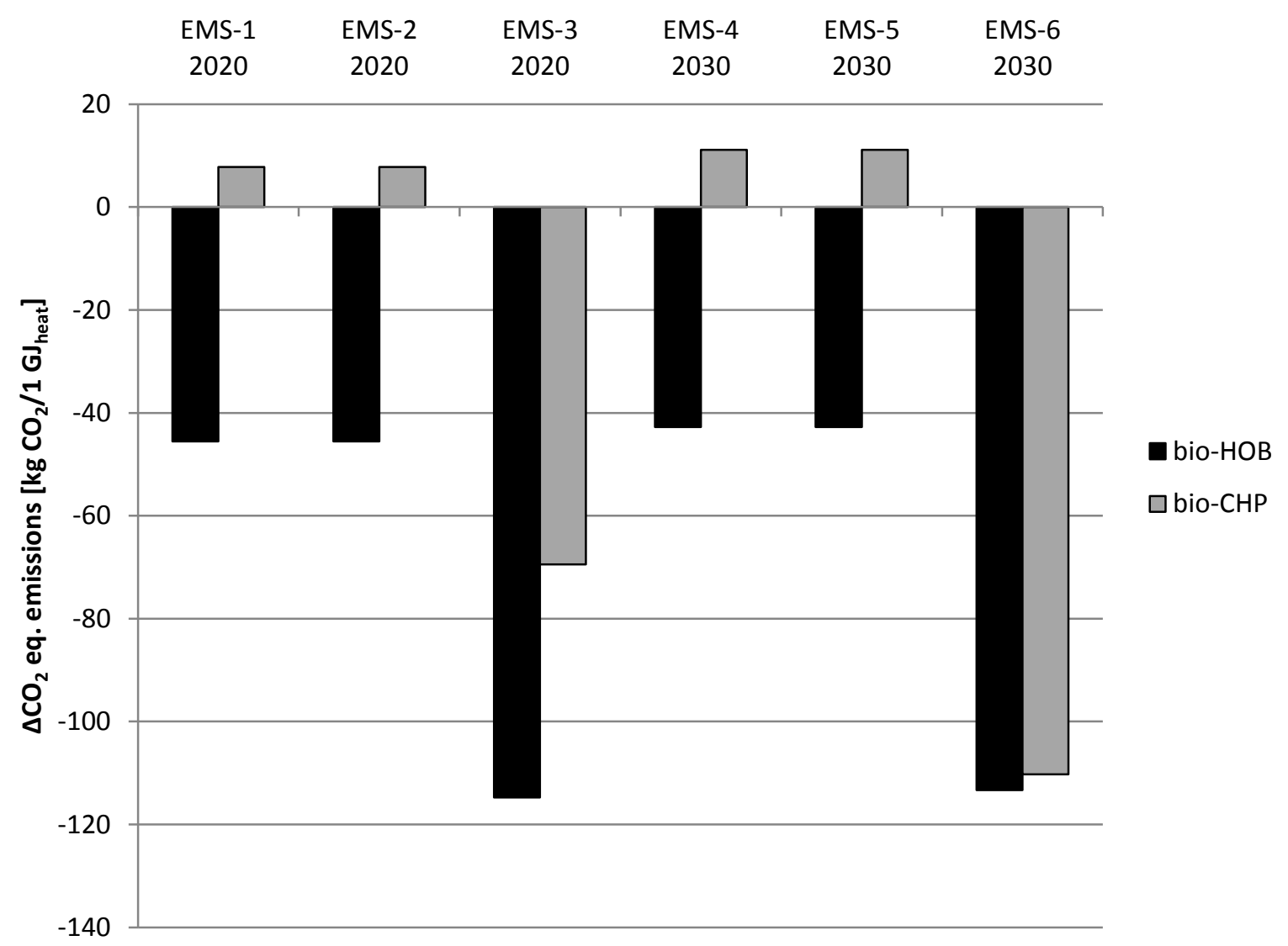

Figure $4 \mathrm{CO}_{2}$-eq. emission reductions in the system calculated using ENPAC for six energy market scenarios for 2020 and 2030, EMS-1 to EMS-6. The graph shows the delta GHG emissions compared to not using excess heat in the system. A negative value means that there is a positive effect on GHG emissions. Positive values mean that the overall system emissions increase due to excess heat utilization in DH systems.

GHG emissions increase in four scenarios when the DH is CHP-based, that is EMS-1, -2, -4, and -5. Replacing part of the thermal source in a CHP-based DH system with industrial excess heat not only reduces the heat production from the CHP plant but also the electricity production. The electricity demand will then be met by introducing the marginal technology, coal power plants, in the four scenarios with increased emissions. In these scenarios the released biomass will be used for production of biofuels, FT diesel. The difference in emission consequences between EMS-3 and EMS-6 compared to EMS-1, -2, -4, -5 is mainly due to two factors: the reductions associated with the use of biomass (see Table 2) and the efficiency differences for the different uses for biomass, which is higher when using biomass for co-combustion in coal power plants compared to using biomass for FT-diesel production. As a consequence, GHG benefits with excess heat use will be lost in EMS-1, -2, -4, and -5. 


\section{Concluding discussion}

The results show that whether it is "beneficial" from a GHG perspective to use industrial excess heat in DH depends on two main factors: whether DH heat is supplied by HOB or CHP plants, and the choice of system boundaries for the analysis of CHP-based systems. If industrial excess heat is seen as a free resource, and $\mathrm{DH}$ heat is produced in HOB, it is positive to use industrial excess heat in DH. When more fossil fuels are used in the HOB, excess heat in DH leads to the largest reduction of GHG emissions, as in the winter scenario in the contemporary system and the 2020 ENPAC scenarios.

For CHP-based DH, the effects on GHG emissions depend on how "lost" electricity production is valued and the alternative use of unused fuel. If the "lost" electricity production is allocated high emissions of GHG - for example if the alternative electricity production comes from a coal-based production system such as the European average - the use of industrial excess heat in DH leads to increased emissions. This means that in a contemporary setting it is not beneficial to use industrial excess heat in CHP-based DH systems. In the future scenarios when marginal electricity production is replaced by NGCC, the use of industrial excess heat in CHP-based DH will consequently be less unfavorable.

Calculations made in this article show that the most important factor influencing the system effects on GHG emissions is the possibility of using "released" biomass. If the biomass is used for co-combustion in coal-based condense power plants, GHG emissions may be reduced substantially. This means that only if there is a biomass fuel market steering towards the most "effective" use of biomass (from a GHG perspective), can the full potential for the use of industrial excess heat in DH be realized with a resultant reduction in total GHG emissions.

As was mentioned in the introduction, Swedish policy regarding the use of excess heat in DH is ambiguous. It neither clearly encourages nor discourages using industrial excess heat in DH. In the light of this study it may seem an unnecessary precaution, as the effects on total GHG emissions are positive when the DH originates from HOB. When it is technically feasible to use industrial excess heat in $\mathrm{DH}$, this should be promoted as a GHG mitigation measure. On the other hand, for the more complex CHP-based DH systems, the precautions in the Swedish policy can be supported, at least in the shorter term.

District heating systems are, however, long-term investments, which means that future conditions also have to be taken into consideration when making decisions about heat production. With a future well-functioning biomass market, industrial excess heat could also lead to considerable reductions in GHG emissions in CHP-based DH systems. A strengthened EU-policy recommending the use of biomass where it has the most favorable effects from a systems perspective is therefore necessary in order to realize the full potential of using industrial excess heat in district heating.

\section{Acknowledgments}

This work was carried out under the auspices of the Energy Systems Programme, funded by the Swedish Energy Agency. The authors would like to express their gratitude to Anton 
Helgstrand at the Division of Environmental Technology and Management, Linköping University, for his help with the LCA calculations, and to Associate Professor Magnus Karlsson at the Division of Energy Systems, Linköping University, for his support and valuable comments.

\section{References}

Axelsson, E., Harvey, S., Berntsson, T., 2009. A tool for creating energy market scenarios for evaluation of investments in energy intensive industry. Energy 34, 2069-2074.

Axelsson, E., Pettersson, K., 2014. Energy price and Carbon Balance Scenarios tool (ENPAC) - a summary of recent updates Chalmers university of Technology

Broberg, S., Backlund, S., Karlsson, M., Thollander, P., 2012. Industrial excess heat deliveries to Swedish district heating networks: Drop it like it's hot. Energy Policy 51, 332-339.

Broberg Viklund, S., 2014. Energy efficiency through industrial excess heat recovery—policy impacts. Energy Efficiency, 1-17.

Broberg Viklund, S., Johansson, M.T., 2014. Technologies for utilization of industrial excess heat: Potentials for energy recovery and CO2 emission reduction. Energy Conversion and Management 77, 369-379.

Connolly, D., Lund, H., Mathiesen, B.V., Werner, S., Möller, B., Persson, U., Boermans, T., Trier, D., Østergaard, P.A., Nielsen, S., 2014. Heat Roadmap Europe: Combining district heating with heat savings to decarbonise the EU energy system. Energy Policy 65, 475-489.

Connolly, D., Vadmathiesen, B., Alberg Ostergaard, P., Moller, B., Nielsen, S., Lund, H., Trier, D., Persson, U., Nilsson, D., Werner, S., 2012. Heat roadmap Europe 2050.

Cronholm, L.-Å., Grönkvist, S., Saxe, M., 2009. Excess heat from industries and premises [Spillvärme från industrier och värmeåtervinning från lokaler] -in Swedish Stockholm, Sweden

Cruz, E., Vatanakul, M., Hynes, R., Sarvinis, J., McKenna, K., 2011. Waste heat utilization to increase energy efficiency in the metals industry In: Energy technology 2011: Carbon dioxide and other greenhouse gas reduction metallurgy and waste heat recovery John Whiley \& Sons, Hoboken, NJ, USA.

Dotzauer, E., 2010. Greenhouse gas emissions from power generation and consumption in a nordic perspective. Energy Policy 38, 701-704. 
Ecoinvent Centre, 2010. Ecoinvent data, version 2.2. The Centre for Life Cycle Inventories.

English, M.R., Dale, V.H., Riper-Geibig, C.V., Ramsey, W.H., 1999. Overview, in: Dale, V.H., English, M.R. (Eds.), Tools to aid Environmental Decision Making. Springer, New York, pp. 1-31.

Eriksson, O., Finnveden, G., Björklund, A., Ekvall, T., 2007. Life cycle assessment of fuels for district heating: A comparison of waste incineration, biomass- and natural gas combustion. Energy Policy 35, 1346-1362.

European Commission, 2010. Europe 2020: a strategy for smart, sustainable and inclusive growth: communication from the Commission.

European Commission, 2011. Communication from the Commission to the European Parliament, the Council, the European Economic and Social Committe and the Commitee of the Regions - Energy Efficiency Plan 2011. European Commission, Brussels.

European Commission, 2012. Directive 2012/27/EU of the European Parliament and of the Council of 25 October 2012 on energy efficiency. European Cimmission, Brussels

European Commission, 2014. Climate Action - 2030 framework for climate and energy policies. European Commission.

Ghafghazi, S., Sowlati, T., Sokhansanj, S., Bi, X., Melin, S., 2011. Life cycle assessment of base-load heat sources for district heating system options. International Journal of Life Cycle Assessment 16, 212-223.

Gode, J., Martinsson, F., Hagberg, L., Öman, A., Höglund, J., Palm, D., 2011. Environmental facts book 2011 - Estimated emission factors for fuel, electricity, heat, and transports [Miljöfaktaboken 2011-Uppskattade emissionsfaktorer för bränslen, el, värme och transporter] in Swedish. Värmeforsk rapport 1183.

Grönkvist, S., Dahlberg, L., Lundberg, H., Martinsson, C., Stenkvist, M., 2008. Analysis of methods to increase the incentives for excess heat use [Analys av metoder för att öka incitament för spillvärmesamarbete] - in Swedish Eskilstuna, Sweden

Guest, G., Bright, R.M., Cherubini, F., Michelsen, O., Strømman, A.H., 2011. Life cycle assessment of biomass-based combined heat and power plants: Centralized versus decentralized deployment strategies. Journal of Industrial Ecology 15, 908-921. 
Harvey, S., Axelsson, E., 2010. Scenarios for assessing profitability and carbon balances of energy investments in industry. Chalmers University of Technology.

Hochschorner, E., Finnveden, G., 2003. Evaluation of two simplified Life Cycle assessment methods. Int J LCA 8, 119-128.

Holmgren, K., Sjödin, J., 2008. Policy instruments for excess heat [Styrmedel för industriell spillvärme] - in Swedish

IEA, 2011. World Energy Outlook 2011, Paris, France.

ISO, 2006a. Environmental management - Life cycle assessment - principles and framework.

ISO, 2006b. Environmental management - Life cycle assessment - Requirements and guidelines.

Johansson, D., Franck, P.-Å., Berntsson, T., 2013. CO2 capture in oil refineries: Assessment of the capture avoidance costs associated with different heat supply options in a future energy market. Energy Conversion and Management 66, 127-142.

Jönsson, J., Svensson, I.-L., Berntsson, T., Moshfegh, B., 2008. Excess heat from kraft pulp mills: Trade-offs between internal and external use in the case of Sweden-Part 2: Results for future energy market scenarios. Energy Policy 36, 4186-4197.

Knutsson, D., Werner, S., Ahlgren, E.O., 2006. Combined heat and power in the Swedish district heating sector-impact of green certificates and $\mathrm{CO} 2$ trading on new investments. Energy Policy 34, 3942-3952.

Ministry of Enterprise Energy and Communications, 2013. Proposal for implementation of the energy efficiency directive in Sweden N2013/2873/E [Promemoria - Förslag till genomförande av energieffektiviseringsdirektivet i Sverige N2013/2873/E] - in Swedish Stockholm, Sweden.

Nomura, T., Okinaka, N., Akiyama, T., 2010. Waste heat transportation system, using phase change material (PCM) from steelworks to chemical plant. Resources, Conservation and Recycling 54, 10001006.

Persson, U., Nilsson, D., Möller, B., Werner, S., 2012. Mapping local European heat resources - A spatial approach to identify favorable synergy regions for district ehating DHC13, the 13th International Smposium on District Heating and Cooling Copenhagen, Denmark 
Persson, U., Werner, S., 2012. District heating in sequential energy supply. Applied Energy 95, 123131.

Pietrapertosa, F., Cosmi, C., Macchiato, M., Salvia, M., Cuomo, V., 2009. Life Cycle Assessment, ExternE and Comprehensive Analysis for an integrated evaluation of the environmental impact of anthropogenic activities. Renewable and Sustainable Energy Reviews 13, 1039-1048.

Product Ecology (PRé) consultants, 2008. Introduction to LCA with SimaPro 7, Report 4.2.

Ruohonen, P., Hippinen, I., Tuomaala, M., Ahtila, P., 2010. Analysis of alternative secondary heat uses to improve energy efficiency—case: A Finnish mechanical pulp and paper mill. Resources, Conservation and Recycling 54, 326-335.

SEA, 2010. Electricity certificate system 2010 [Elcertifikatsystemet 2010]. Swedish Energy Agency Eskilstuna, Sweden

Sjödin, J., Grönkvist, S., 2004. Emissions accounting for use and supply of electricity in the Nordic market. Energy Policy 32, 1555-1564.

SOU (Ministry of Enterprise Energy and Communications), 2005. District heating and combined heat and power in the future SOU 2005:33 [Fjärrvärme och kraftvärme i framiden SOU 2005:33] - in Swedish.

SOU (Ministry of Enterprise Energy and Communications), 2011. DH on a competitive market, reflections on TPA SOU 2011:44 [Fjärrvärme i konkurrens, betänkande av TPA utredningen SOU 2011:44] - in Swedish. Fritzes Offentliga Publikationer Stockholm, Sweden

Swedish District Heating Association, 2005. Förnybar ersättning av olja i spetslastproduktion, Rapport 2006:5.

Swedish District Heating Association, 2014. Statistics district heating [Statistik fjärrvärme]

Swedish District heating Association, Svensk energi, 2011. Miljövärdering 2011 - Guide för allokering i kraftvärmeverk och fjärrvärmens elanvändning (Environmental Assessment 2011 - guide to allocation for CHP and electricity used in district heating - in Swedish).

Swedish Government, 2014. Government bill 2013/14:187 Regulated access to the district heating networks [Regeringens proposition 2013/14:187 Reglerat tillträde till fjärrvärmenäten] - in Swedish 
Thekdi, A., Belt, C., 2011. Waste heat reduction and recovery options for metals industry In: Energy technology 2011: Carbon dioxide and other greenhouse gas reduction metallurgy and waste heat recovery John Whiley \& Sons, Hoboken, NJ, USA.

Uppenberg, S., Almemark, M., Brandel, M., Lindfors, L.g., Marcus, H.-O., Stripple, H., Wachtmeister, A., Zetterberg, L., 2001. Miljöfaktabok för bränslen (Environmental facts for fuels - in Swedish). Swedish Environment Research Institute.

Wrisberg, N., Udo de Haes, H.A.E., 2002. Analytical Tools for Environmental Design and Management in a System Perspective: The Combined Use of Analytical Tools. Kluwer Academic Publishers. 